2014

\title{
New Radiocarbon Dates from the Shelby Mound Site (41CP71) on Greasy Creek in the Big Cypress Creek Basin of East Texas
}

Timothy K. Perttula

Heritage Research Center, Stephen F. Austin State University

Robert Z. Selden Jr.

Heritage Research Center, Stephen F. Austin State University

Follow this and additional works at: https://scholarworks.sfasu.edu/ita

Part of the American Material Culture Commons, Archaeological Anthropology Commons, Environmental Studies Commons, Other American Studies Commons, Other Arts and Humanities Commons, Other History of Art, Architecture, and Archaeology Commons, and the United States History Commons

Tell us how this article helped you.

This Article is brought to you for free and open access by the Center for Regional Heritage Research at SFA ScholarWorks. It has been accepted for inclusion in Index of Texas Archaeology: Open Access Gray Literature from the Lone Star State by an authorized editor of SFA ScholarWorks. For more information, please contact cdsscholarworks@sfasu.edu. 
New Radiocarbon Dates from the Shelby Mound Site (41CP71) on Greasy Creek in the Big Cypress Creek Basin of East Texas

\section{Creative Commons License}

(c) (1) (5)

This work is licensed under a Creative Commons Attribution-NonCommercial 4.0 International License 


\title{
New Radiocarbon Dates from the Shelby Mound Site (41CP71) on Greasy Creek in the Big Cypress Creek Basin of East Texas
}

\author{
Timothy K. Perttula and Robert Z. Selden, Jr.
}

\section{INTRODUCTION}

Six new radiocarbon dates have been obtained from the Shelby Mound site (41CP71) in the Big Cypress Creek basin in East Texas. They are on charred organic remains - corn cupules and glumes and Hickory (Carya sp.) nutshell-identified in several levels in and immediately below the mound deposits.

The Shelby Mound site on Greasy Creek is the social and political center of an ancestral Caddo Greasy Creek political community. It stretches for several hundred meters along Greasy Creek and a small tributary, with an earthen mound at the northern end of the village and a large cemetery at its southern end. Domestic village areas are between the mound and the cemetery and cover at least 10-15 acres (Perttula and Nelson 2004). The Titus phase earthen mound covered a burned structure at the base of the mound, and a second structure had been built that stood on the mound itself, and was then burned and capped first with clay and then with a final sandy fill intermixed with midden deposits. The arrangement of the mound, domestic areas, and planned cemetery here is essentially duplicated at other important Titus phase communities in the Big Cypress Creek basin, although the village areas and the size of the cemetery at the Shelby Mound site are considerably larger than most of the others (Perttula 2012). Based on work at the site in 2002, the north levee area at the Shelby Mound site was found to have thick midden deposits and evidence for several burned structures (Perttula and Nelson 2004), implying the existence of an intensive occupation throughout the life of the community.

\section{NEW RADIOCARBON DATES}

The conventional ${ }^{14} \mathrm{C}$ dates of the six new dates (D-AMS 4323 to D-AMS 4328) from the Shelby Mound site were recalibrated using OxCal 4.2.3 (Bronk Ramsey 2013) and IntCal13 (see discussion in Selden and Perttula 2013), as were the previous nine dates from the site. Table 1 includes contextual information on each of the samples, 1 and 2 sigma calibrated age ranges, and the median calibrated age (per OxCal) for all 15 samples from the site. There are four radiocarbon dates from village areas (Perttula and Nelson 2004), one date on a cedar pole placed in a burial in the community cemetery (Perttula 2009), one radiocarbon date on organic residue preserved on a utility ware ceramic vessel from a burial in the cemetery (Perttula and Selden 2013), and nine dates from various levels in the one mound at the Shelby Mound site.

\section{RADIOCARBON DATES BY CONTEXT FROM THE SITE}

As previously mentioned, one of the dates from the site comes from a sample of wood taken from a 9 $\mathrm{ft}$. long red cedar pole recovered from a shaft tomb in the large community cemetery at the site (Perttula 2009:20-21). The radiocarbon sample returned a 2 sigma (95\% probability) calibrated age range of A.D. 1441-1637, with a median calibrated age of A.D. 1521 (see Table 1). This places the date comfortably in the Titus phase, which has been estimated to date from ca. A.D. 1430-1680 (Perttula 2012). 
Table 1. Radiocarbon Dates from the Shelby Mound Site.

\begin{tabular}{|c|c|c|c|c|}
\hline Sample No. & Context & $\begin{array}{l}1 \text { Sigma Cal. } \\
\text { (A.D.) }\end{array}$ & $\begin{array}{l}2 \text { Sigma Cal. } \\
\text { (A.D.) }\end{array}$ & $\begin{array}{l}\text { Median Cal. } \\
\text { Age (A.D.) }\end{array}$ \\
\hline \multicolumn{5}{|l|}{ Village } \\
\hline B-181794 & $\begin{array}{l}\text { Unit } 3,40- \\
50 \mathrm{~cm} \mathrm{bs}\end{array}$ & $\begin{array}{l}1275-1318(0.37) \\
1352-1390(0.32)\end{array}$ & $1251-1411(0.95)$ & 1324 \\
\hline B-181792 & $\begin{array}{l}\text { Feature } 9 \text {, } \\
\text { Unit } 3\end{array}$ & $\begin{array}{l}1396-1445(0.61), \\
1329-1340(0.08)\end{array}$ & $\begin{array}{l}1384-1463(0.72), \\
1305-1365(0.24)\end{array}$ & 1415 \\
\hline B-181795 & $\begin{array}{l}\text { Unit } 3,60- \\
70 \mathrm{~cm} \mathrm{bs}\end{array}$ & $\begin{array}{l}1435-1515(0.57), \\
1598-1618(0.11)\end{array}$ & $\begin{array}{l}1420-1529(0.65), \\
1544-1635(0.30)\end{array}$ & 1491 \\
\hline B-181793 & $\begin{array}{l}\text { ST } 3,40-50 \\
\text { cm bs }\end{array}$ & $\begin{array}{l}1558-1631(0.40) \\
1473-1525(0.23)\end{array}$ & $1452-1642(0.95)$ & 1550 \\
\hline \multicolumn{5}{|c|}{ Cedar Pole from Burial in the Cemetery } \\
\hline B-244934 & - & $\begin{array}{l}1448-1522(0.45) \\
1590-1625(0.19)\end{array}$ & $1441-1637(0.95)$ & 1521 \\
\hline \multicolumn{5}{|c|}{ Vessel from Cemetery } \\
\hline D-AMS 1429 & Jar residue & $\begin{array}{l}1523-1572(0.41), \\
1630-1655(0.27)\end{array}$ & $\begin{array}{l}1512-1572(0.57), \\
1616-1665(0.37)\end{array}$ & 1572 \\
\hline \multicolumn{5}{|c|}{ Mound and Sub-Mound Deposits } \\
\hline $\begin{array}{l}\text { Level } 8 \\
\text { B-132852 }\end{array}$ & Carya sp. & $\begin{array}{l}1452-1523(0.39) \\
1572-1630(0.30)\end{array}$ & $1440-1644(0.95)$ & 1537 \\
\hline \multicolumn{5}{|l|}{ Level 9} \\
\hline B-132853 & Carya sp. & $\begin{array}{l}1392-1444(0.50) \\
1321-1349(0.19)\end{array}$ & $1296-1466(0.95)$ & 1405 \\
\hline D-AMS 4326 & Carya sp. & $\begin{array}{l}1394-1417(0.40), \\
1325-1344(0.28)\end{array}$ & $\begin{array}{l}1387-1430(0.51), \\
1312-1359(0.44)\end{array}$ & 1393 \\
\hline \multicolumn{5}{|l|}{ Level 9/10 } \\
\hline \multicolumn{5}{|l|}{ Level 10} \\
\hline D-AMS 4327 & corn & $\begin{array}{l}1455-1497(0.48) \\
1601-1616(0.16)\end{array}$ & $\begin{array}{l}1448-1523(0.66) \\
1574-1627(0.29)\end{array}$ & 1497 \\
\hline D-AMS 4323 & corn & $\begin{array}{l}1441-1499(0.54), \\
1601-1616(0.11)\end{array}$ & $\begin{array}{l}1432-1525(0.69), \\
1558-1632(0.26)\end{array}$ & 1485 \\
\hline \multicolumn{5}{|l|}{ Level 10/11 } \\
\hline B-132851 & Carya sp. & $\begin{array}{l}1267-1309(0.45) \\
1361-1387(0.23)\end{array}$ & $\begin{array}{l}1245-1331(0.60) \\
1338-1398(0.35)\end{array}$ & 1302 \\
\hline \multicolumn{5}{|l|}{ Level 11} \\
\hline D-AMS 4324 & Carya sp. & $\begin{array}{l}1632-1655(0.35) \\
1526-1556(0.33)\end{array}$ & $\begin{array}{l}1520-1593(0.50), \\
1619-1665(0.45)\end{array}$ & 1586 \\
\hline D-AMS 4328 & Carya sp. & $\begin{array}{l}1467-1516(0.47), \\
1596-1618(0.22)\end{array}$ & $\begin{array}{l}1453-1524(0.58) \\
1571-1631(0.37)\end{array}$ & 1511 \\
\hline
\end{tabular}

$\mathrm{B}=$ Beta Analytic $; \mathrm{D}-\mathrm{AMS}=$ Direct AMS 
A second radiocarbon date is on organic residue collected from the surface of a medium-sized incisedappliqued jar from the site that is now in the Margaret Hinton collection at Northeast Texas Community College (Perttula et al. 2012; Perttula and Selden 2013). The organic residue has 2 sigma calibrated age ranges of A.D. 1512-1602 (57\% probability) and A.D. 1616-1665 (37\%), with a median calibrated age of A.D. 1572 (see Table 1).

There are four dates from village deposits. The median calibrated ages of these samples range from A.D. 1324 to A.D. 1550 (see Table 1), suggesting an occupation that may have begun in the 14th century in the Middle Caddo period, and then a second and more extensive occupation that lasted from A.D. 1415-1550, during the Late Caddo period Titus phase. The earliest village data has a 2 sigma age range of A.D. 12511411, suggesting the village occupation may have begun as early as the 13th century A.D. ranging to as late as the first part of the 15th century. The highest probabilities associated with the other three dates are A.D. 1384-1463 (0.72), A.D. 1420-1529 (0.65), and A.D. 1452-1642 (0.95) (see Table 1), all with age ranges that fall within the Titus phase temporal interval.

The single mound at the Shelby Mound site is ca. $18.3 \mathrm{~m}$ in diameter and stands approximately $1.5 \mathrm{~m}$ in height. Between 1985-1988, Robert L. Turner and Ralph Nicholas excavated a single 10 x $10 \mathrm{ft}$. unit in the mound. These units were excavated in $0.5 \mathrm{ft}$. levels (ca. $15 \mathrm{~cm}$ thick), beginning with level 1 , the uppermost surface level. Level 1 had a bottom elevation of $102.0 \mathrm{ft}$. Excavations reached the base of the mound in Level 10 (98.0-97.5 ft. in elevation), and there are sub-mound archaeological deposits in Levels 10/11 and 11 (97.5-97.0 ft. in elevation).

Based on available profiles and profile descriptions, the mound was apparently constructed with sediments and midden refuse collected from the adjoining village deposits and nearby stream deposits. The mound was built over a burned structure that would have stood on the pre-mound surface in Level 10/11 and 11; this structure was marked by an arc of five post holes that appear to have originated at about 97.0 $\mathrm{ft}$. bs. The burned structure may have been built in the latter part of the $15^{\text {th }}$ century, based on median calibrated ages of A.D. 1485 and A.D. 1497 from Level 10 deposits (see Table 1). Earlier and later calibrated ages for samples in Level 10/11 and 11 likely reflect the use of earlier midden deposits as mound fill as well as later intrusive features and organic remains from an overlying and second burned structure (exposed in Level 8). The sub-mound Titus phase structure was covered with about 1.0-1.5 ft. of sediments, after which a second structure was erected atop the mound. This structure was marked by an arc of circular post holes (see Perttula and Nelson 2004:Figure 15) at elevations of 98.9-98.5 ft. (level 8), as well as charcoal and ash, charcoal-stained soil, and oxidized sand. These deposits indicate the second structure was burned, probably deliberately; this burning may have taken place around A.D. 1537, based on this median calibrated age range of A.D. 1537 (and a 2 sigma age range of A.D. 1440-1644) on charred Carya sp. plant remains from Level 8.

After the structure was burned, tan sand and grayish-blue clay sediments were placed over the burned house debris; these sediments occur in levels 6 and 7 (100.0-99.5 ft. bs). The mound deposits above $100.0 \mathrm{ft}$. bs are comprised of sandy loams of varying colors, midden deposits with considerable numbers of ceramic sherds and some animal bones, along with mottled sand and clay, and individual basket loads of mound fill (Perttula and Nelson 2004:Figure 16). It is likely that these separate mound fill zones were deposited shortly after the structure was burned.

\section{SUMMED PROBABILITY DISTRIBUTION}

The 2 sigma calibrated age ranges of the 15 radiocarbon dates from the Shelby Mound site places the initial occupation of this site as early as A.D. 1245-1331 and A.D. 1251-1411 from a village area and submound deposits, indicating some habitation use of the site in the Middle Caddo period. The remaining 13 radiocarbon dates are from the Titus phase Caddo use of the site as a village, a community cemetery, and a mound center. 
The summed probability distribution of these dates indicates that the probability densities increase from an initial occupation during the 13th and 14th centuries A.D. (with a peak at ca. A.D. 1340) to a more substantial occupation that ranges from the first quarter of the 15th century A.D. to the first quarter of the 16th century A.D., with a notable peak at ca. A.D. 1440 (Figure 1). A second probability density peak occurs in the early 17 th century A.D.

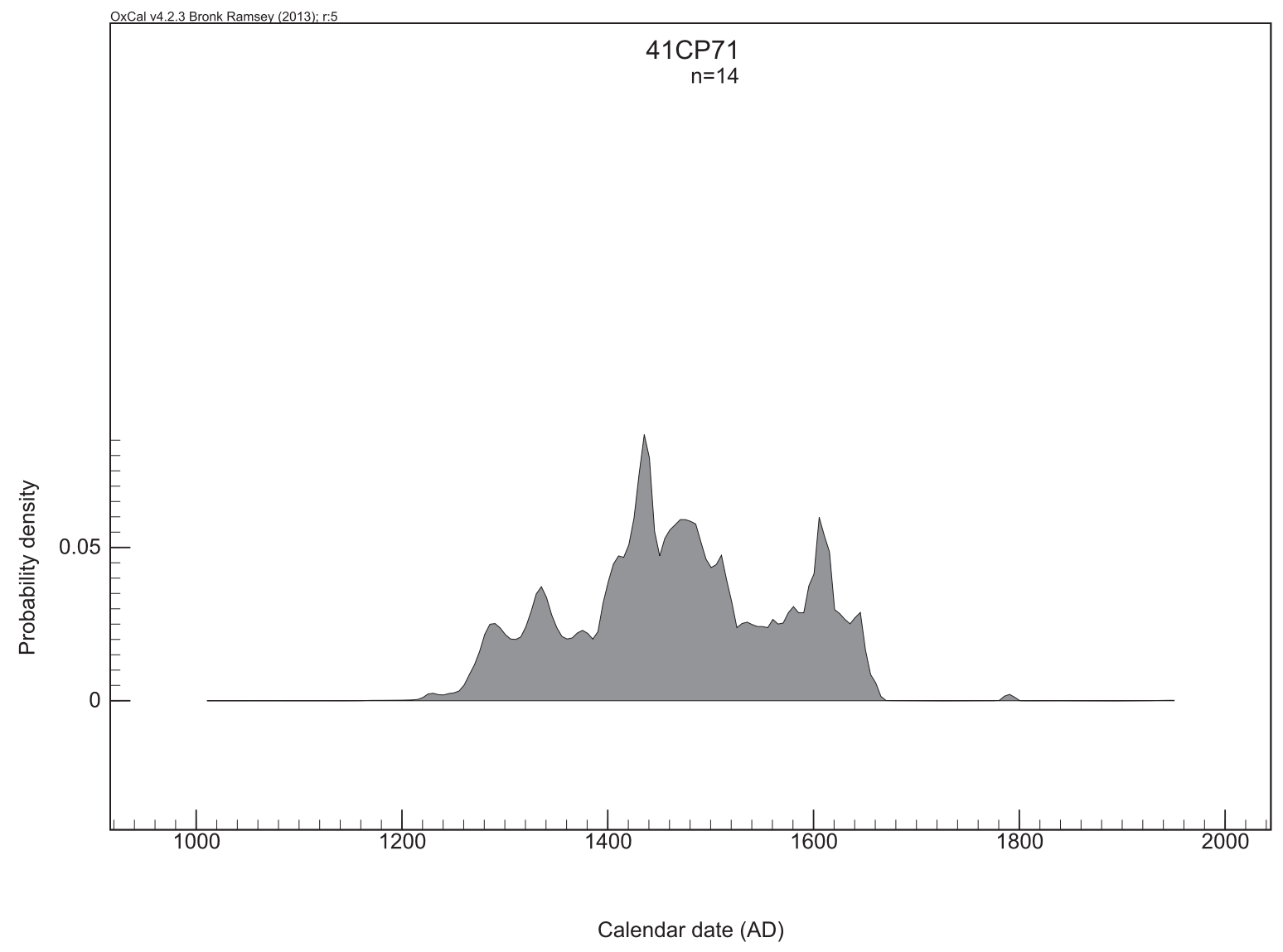

Figure 1. Summed probability distribution of calibrated radiocarbon dates from the Shelby Mound site.

\section{CONCLUSIONS}

With the six new radiocarbon dates on organic remains recovered from the mound deposits at the Shelby Mound site, there are now 15 radiocarbon dates from the site (see Table 1). First, the 2 sigma calibrated age ranges of the dates from the Shelby Mound site point to the existence of 14th century A.D. village areas and sub-mound deposits (two dates, one from the village and the other from sub-mound deposits). The remaining 13 radiocarbon dates are from the Titus phase Caddo use of the site as a village, a community cemetery, and a mound center.

The more substantial occupation of the Shelby Mound site dates to the Late Caddo period Titus phase. Village occupation began around the first quarter of the 15th century and lasted until at least A.D. 1550. The two dates from cemetery contexts indicate that the cemetery was being used during the early and late 16th century. The mound appears to have been built over a structure that was burned in the final years of the 15th century A.D. (with median calibrated ages of A.D. 1485 and A.D. 1497), and a second structure atop the mound platform was subsequently built and burned during the mid-16th century A.D. (median calibrated age of A.D. 1537). 


\section{REFERENCES CITED}

Bronk Ramsey, C.

2013 OxCal 4.1.7.Electronic resource, https://c14.arch.ox.ac.uk/login/login.php?Location=/oxcal/OxCal.html, accessed December 30, 2013.

Perttula, T. K.

2009 A Radiocarbon Date from a Cedar Pole in a Special Caddo Burial Feature at the Shelby Mound site (41CP71). Texas Archeology (Newsletter of the Texas Archeological Society) 53(1):20-21.

2012 The Character of $15^{\text {th }}$ to $17^{\text {th }}$ Century Caddo Communities in the Big Cypress Creek Basin of Northeastern Texas. In The Archaeology of the Caddo, edited by T. K. Perttula and C. P. Walker, pp. 363-410. University of Nebraska Press, Lincoln.

Perttula, T. K. and B. Nelson

2004 Archeological Investigations at the Shelby Site (41CP71) on Greasy Creek, Camp County, Texas. Special Publication No. 5. Friends of Northeast Texas Archaeology, Pittsburg and Austin.

Perttula, T. K. and R. Z. Selden, Jr.

2013 New Radiocarbon Dates from East Texas Caddo Sites. Journal of Northeast Texas Archaeology 40:1926.

Perttula, T. K., P. S. Marceaux, and B. Nelson

2012 Study of the Margaret Hinton Collection of Pottery Vessels from Northeast Texas Caddo Cemeteries. Special Publication No. 24. Friends of Northeast Texas Archaeology, Austin and Pittsburg.

Selden Jr., R. Z. and T. K. Perttula

2013 Radiocarbon Trends and the East Texas Caddo Tradition (ca. A.D. 800-1680). Southeastern Archaeology 32(1):85-96. 